\title{
A heterobimetallic copper-titanium oxo cluster with a new structural motif
}

\author{
Christine Artner $^{1} \cdot$ Ayse Koyun $^{1} \cdot$ Ulrich Schubert $^{1}$
}

Received: 9 May 2015/Accepted: 9 August 2015/Published online: 1 September 2015

(c) The Author(s) 2015. This article is published with open access at Springerlink.com

\begin{abstract}
Mixed-metal oxo clusters $\mathrm{Cu}_{4} \mathrm{Ti}_{5} \mathrm{O}_{6}(\mathrm{OOCR})_{16}$ $(\mathrm{OOCR}=$ methacrylate, propionate $)$ were obtained by reaction of titanium alkoxides and copper carboxylates with propionic or methacrylic acid.
\end{abstract}

Graphical abstract

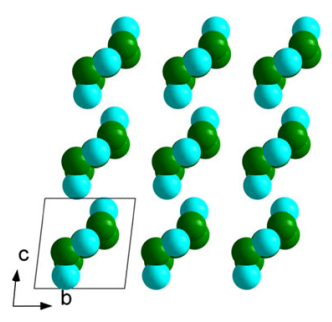

Keywords Metal oxo clusters · Copper compounds . Titanium compounds

\section{Introduction}

Metal oxo clusters can be obtained by controlled hydrolysis of metal alkoxides and regarded as intermediates or building blocks in the formation of sol-gel materials. They may also serve as model compounds for structural units in amorphous gels. Especially for bimetallic gels, nearly nothing is known about distribution and mutual arrangement of the metals. The structural characterization of

Ulrich Schubert

Ulrich.Schubert@tuwien.ac.at

1 Institute of Materials Chemistry, Vienna University of Technology, Getreidemarkt 9, 1060 Vienna, Austria heterobimetallic oxo clusters may therefore provide some evidence in this respect.

Schubert et al. have previously developed a convenient approach to synthesize heterobimetallic oxo clusters with early transition metals (Ti, Zr, Y) as one of the metals. To this end, carboxylic acids were initially reacted with metal alkoxide mixtures. The oxo groups of the cluster core are produced in situ through esterification of the carboxylic acid with alcohol which is liberated by substitution of alkoxo ligands against carboxylate ligands. A simplification of this method is to use only one metal alkoxide, and a metal acetate as the source for the second metal [1-3].

The structures of most titanium-containing heterobimetallic clusters are based on a few common motifs, despite variation of coordination number, ionic size, and charge of the second metal. Some clusters with $\mathrm{Pb}, \mathrm{Sr}$ [1], $\mathrm{La}$, and $\mathrm{Ce}$ [2] are structurally derived from cyclic $\mathrm{Ti}_{8} \mathrm{O}_{8}(\mathrm{OOCR})_{16}$. Another series is based on partial replacements of the Ti atoms in $\mathrm{Ti}_{6} \mathrm{O}_{4}(\mathrm{OR})_{8}(\mathrm{OOCR})_{8}$ by $\mathrm{Fe}, \mathrm{Zn}, \mathrm{Cd}, \mathrm{Ca}$, or $\mathrm{Sr}$, with concomitant rearrangement of the ligand shell [3]. The structures of clusters with $\mathrm{Zr}$ [4], Hf [5], Y [6], Sm, Eu, Gd, or Ho [2] are zig-zag chains of condensed $\left[\mathrm{TiO}_{6}\right]$ and $\left[\mathrm{MO}_{\mathrm{x}}\right]$ polyhedra. In this article, we describe a $\mathrm{Cu} / \mathrm{Ti}$ oxo cluster the structure of which is not related to these series although the radius and coordination properties of $\mathrm{Cu}^{2+}$ ions are not too different to that of other divalent metals used before.

\section{Results and discussion}

When $\mathrm{Ti}(\mathrm{O} i \mathrm{Pr})_{4}, \mathrm{Ti}(\mathrm{OPr})_{4}$, or $\mathrm{Ti}(\mathrm{OBu})_{4}$ were reacted with $\mathrm{Cu}(\mathrm{OAc})_{2}$ and methacrylic acid (HOMc) in different molar ratios, the centrosymmetric heterobimetallic cluster $\mathrm{Cu}_{4} \mathrm{Ti}_{5}\left(\mu_{3}-\mathrm{O}\right)_{6}\left(\mu_{2}-\mathrm{OMc}\right)_{16}$ (1, Fig. 1) was obtained. The 


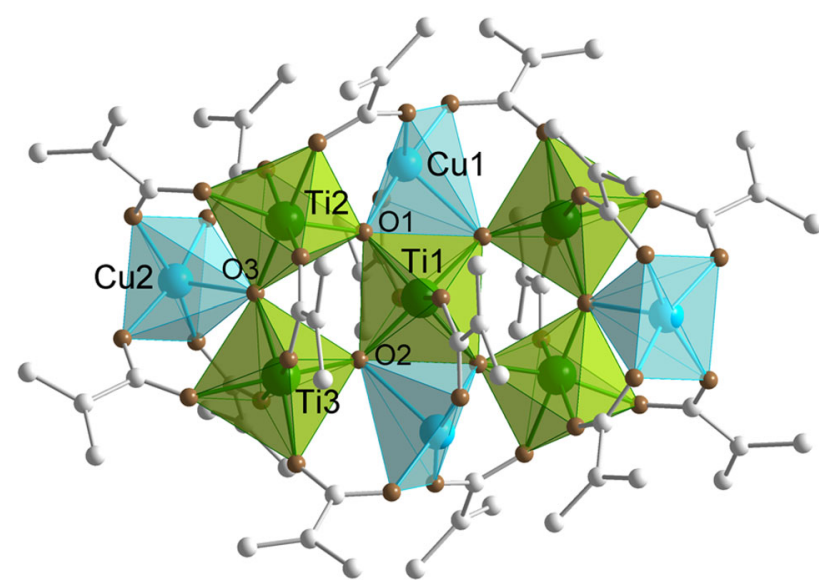

Fig. 1 Molecular structure of $\mathrm{Cu}_{4} \mathrm{Ti}_{5} \mathrm{O}_{6}(\mathrm{OMc})_{16}$ (1). Hydrogen atoms have been omitted for clarity. Cu1-O1 1.9592(12), Cu1-O2 2.3446(12), Cu1-O4 1.9687(13), Cu1-O6 1.9427(13), Cu1-O8 1.9289(13), Cu2-O3 2.1984(12), Cu2-O10 1.9742(14), Cu2-O12 1.9401(14), Cu2-O14 1.9598(14), Cu2-O16 1.9333(14), Ti1-O1 1.9179(11), Ti1-O2 1.9205(12), Ti1-O5 1.9958(12), Ti2-O1 1.8503(12), Ti2-O3 1.7993(12), Ti2-O7 2.0623(13), Ti2-O11 2.0260(13), Ti2-O13 1.9960(12), Ti2-O18 2.0081(13), Ti3-O2 1.7656(12), Ti3-O3 1.9066(12), Ti3-O9 2.0014(13), Ti3-O15 1.9388(13), Ti3-O17 2.1081(13), Ti3-O19 2.0131(13) А

$\mathrm{Cu}: \mathrm{Ti}$ and metal:acid ratio did not influence the formation of $\mathbf{1}$. Some solid $\mathrm{Cu}(\mathrm{OAc})_{2}$ remained unreacted, however, even for a $\mathrm{Cu}: \mathrm{Ti}$ ratio of $4: 5$ and a large excess of methacrylic acid. The formation of known $\mathrm{Ti}_{8} \mathrm{O}_{8}(\mathrm{OMc})_{16}$ $[1,7]$ was supressed by a greater excess of methacrylic acid. The isostructural cluster $\mathrm{Cu}_{4} \mathrm{Ti}_{5} \mathrm{O}_{6}(\mathrm{OProp})_{16}$ (2) was obtained from $\mathrm{Ti}(\mathrm{O} i \mathrm{Pr})_{4}, \mathrm{Cu}(\mathrm{OAc})_{2}$, and propionic acid (HOProp).

The Ti atoms in $\mathbf{1}$ and $\mathbf{2}$ are octahedrally coordinated by six oxygen atoms, the coordination geometry of the copper atoms is a square pyramid. The $\left[\mathrm{TiO}_{6}\right]$ and $\left[\mathrm{CuO}_{5}\right]$ polyhedra are connected through six $\mu_{3}$-oxygen atoms, each of which being bonded to two $\mathrm{Ti}$ and one $\mathrm{Cu}$ atom. The five $\mathrm{Ti}$ atoms and the core oxygen atoms are coplanar; the copper atoms are located above and below the $\mathrm{Ti}_{5} \mathrm{O}_{6}$ plane. While the $\left[\mathrm{TiO}_{6}\right]$ octahedra are corner-sharing among each other and form a face-centred rectangle, two $\left[\mathrm{CuO}_{5}\right]$ square pyramids $(\mathrm{Cu} 2)$ share a corner with two $\left[\mathrm{TiO}_{6}\right]$ octahedra and the other two share an edge with that of central Ti1 (which is located on an inversion centre). The central Ti atom is thus coordinated to four $\mu_{3}-\mathrm{O}$, the other Ti atoms to two $\mu_{3}-\mathrm{O}$, and the $\mathrm{Cu}$ atoms to either one or two.

The apical $\mathrm{Cu}-\mathrm{O}$ distances are longer [Cu1-O2 2.345(1), Cu2-O3 2.198(1) $\AA]$ than the equatorial [1.929(1)1.974(1) $\AA$ ] , and therefore the $\mu_{3}$-oxygen atoms O2 and O3 are unsymmetrically surrounded by the metal atoms. This also influences the $\mathrm{Ti}-\mu_{3}-\mathrm{O}$ distances.

The methacrylate ligands bridge either two Ti atoms, or a $\mathrm{Ti}$ and a $\mathrm{Cu}$ atom. Two OMc ligands bridge the central $\mathrm{Ti}$ atom with $\mathrm{Cu} 1$ on opposite sides of the $\mathrm{Ti}_{5} \mathrm{O}_{6}$ plane. Two
OMc ligands bridge $\mathrm{Cu} 2$ with Ti2 and Ti3 each. The four oxygen atoms of the bridging ligands form the basal plane of the square pyramid of $\mathrm{Cu} 2$. OMc ligands bridge $\mathrm{Cu} 1$ to each of its neighbouring $\mathrm{Ti}$ atoms. The $\mathrm{Cu}-\mathrm{O}$ distances of the ligands are in the range 1.929(1)-1.974(1) $\AA$. The Ti-O bond lengths are in the range 1.939(1)-2.026(1) $\AA$, with only two outliers.

$\mathrm{Cu}_{4} \mathrm{Ti}_{5}\left(\mu_{3}-\mathrm{O}\right)_{6}\left(\mu_{2}-\mathrm{OMc}\right)_{16}$ was also obtained with cocrystallized $\mathrm{CH}_{2} \mathrm{Cl}_{2}(\mathbf{1 S})$. The molecular structure is the same as that of $\mathbf{1}$, but the crystal structure is different (Fig. 2).

\section{Conclusions}

The structures of $\mathrm{Cu}_{4} \mathrm{Ti}_{5} \mathrm{O}_{6}(\mathrm{OOCR})_{16}$ represent a new structural motive, which cannot be derived from known $\mathrm{Ti}$ oxo clusters in a straightforward manner. There is a faint resemblance to the structure of $\mathrm{Zn}_{2} \mathrm{Ti}_{4} \mathrm{O}_{4}(\mathrm{O} i \mathrm{Pr})_{2}(\mathrm{OMc})_{10}$ [3], where two $\left[\mathrm{ZnO}_{4}\right]$ tetrahedra are connected to a ring of four corner-sharing $\left[\mathrm{TiO}_{6}\right]$ octahedra through two $\mu_{3}-\mathrm{O}$ groups. The structure of $\mathbf{1}$ and $\mathbf{2}$ is obtained by cutting the $\mathrm{Zn} / \mathrm{Ti}$ cluster in two halves, replacing the $\left[\mathrm{ZnO}_{4}\right]$ tetrahedra by $\left[\mathrm{CuO}_{5}\right]$ square pyramids and inserting the rod-shaped unit $\mathrm{Cu} 1-\mathrm{Ti} 1-\mathrm{Cu} 1 *$ unit between both halves.

Formation of oxo clusters by reaction of metal alkoxides and carboxylic acids usually depends to a considerable degree on the OR groups of the employed metal alkoxide as well as the kind of carboxylic acid. This is surprisingly not the case for the $\mathrm{Ti} / \mathrm{Cu}$ cluster type reported in this communication. This cluster type therefore appears to be a thermodynamically favoured structural entity. Another unusual feature is that the cluster contains no residual OR ligands, as in most other titanium/metal oxo clusters isolated until present. Both features may be connected with each other.

\section{Experimental}

All experiments were carried out under $\mathrm{Ar}$ atmosphere using standard Schlenk techniques. $\mathrm{Ti}(\mathrm{OPr})_{4}, \mathrm{Ti}(\mathrm{OBu})_{4}$, and $\mathrm{Cu}(\mathrm{OAc})_{2}$ were obtained from Aldrich, $\mathrm{Ti}(\mathrm{O} i \mathrm{Pr})_{4}$ from ABCR. Water-free copper acetate was obtained by drying in vacuum at $130{ }^{\circ} \mathrm{C}$ over night. The drying process was monitored by IR spectroscopy. $\mathrm{Cu}(\mathrm{OMc})_{2}$ was synthesized according to literature [8].

\section{$\mathrm{Cu}_{4} \mathrm{Ti}_{5}$ clusters}

$\mathrm{Cu}_{4} \mathrm{Ti}_{5} \mathrm{O}_{6}(\mathrm{OMc})_{16}\left(\mathbf{1}, \mathrm{C}_{64} \mathrm{H}_{80} \mathrm{Cu}_{4} \mathrm{O}_{38} \mathrm{Ti}_{5}\right)$

Dry $\mathrm{Cu}(\mathrm{OAc})_{2}(0.363 \mathrm{~g}, 2 \mathrm{mmol})$ and $1.137 \mathrm{~g}$ of $\mathrm{Ti}(\mathrm{O} i \mathrm{Pr})_{4}$ (4 mmol) were reacted with $2.32 \mathrm{~g}$ of methacrylic acid (27 mmol). The $\mathrm{Cu}(\mathrm{OAc})_{2}$ did not dissolve completely, 
Fig. 2 Crystal structure of $\mathrm{Cu}_{4} \mathrm{Ti}_{5} \mathrm{O}_{6}(\mathrm{OMc})_{16}(\mathbf{1}$, left $)$ and $\mathrm{Cu}_{4} \mathrm{Ti}_{5} \mathrm{O}_{6}(\mathrm{OMc})_{16} \cdot \mathrm{CH}_{2} \mathrm{Cl}_{2}(\mathbf{1 S}$, right). Only metal and chlorine atoms were drawn in a space filling model
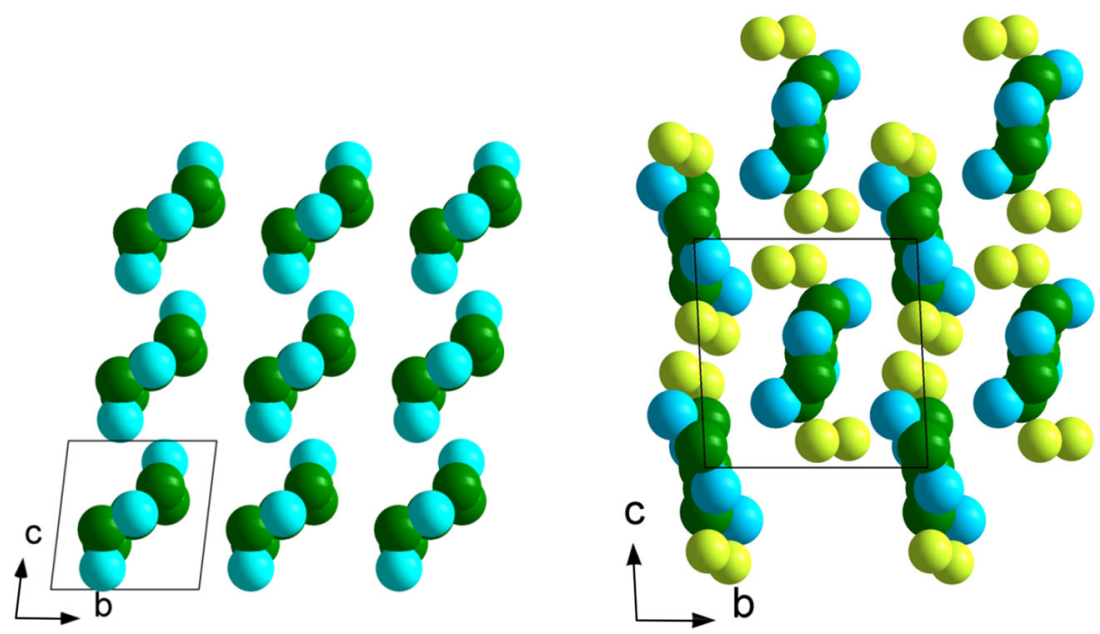

even after stirring for $24 \mathrm{~h}$. The solution was then filtered; dark green crystals of $\mathbf{1}$ formed after 1 week from the filtrate. Yield $0.28 \mathrm{~g}(21 \%$ rel. $\mathrm{Cu})$. After another week white crystals $\mathrm{Ti}_{8} \mathrm{O}_{8}(\mathrm{OMc})_{16}$ [1] were also formed in the same solution.

\section{$\mathrm{Cu}_{4} \mathrm{Ti}_{5} \mathrm{O}_{6}(\mathrm{OMc})_{16} \cdot \mathrm{CH}_{2} \mathrm{Cl}_{2}\left(\mathbf{1 S}, \mathrm{C}_{66} \mathrm{H}_{84} \mathrm{Cl}_{4} \mathrm{Cu}_{4} \mathrm{O}_{38} \mathrm{Ti}_{5}\right)$}

Reaction of $0.935 \mathrm{~g}$ of $\mathrm{Cu}(\mathrm{OMc})_{2}(4 \mathrm{mmol})$ with $1.42 \mathrm{~g}$ of $\mathrm{Ti}(\mathrm{OiPr})_{4} \quad(5 \mathrm{mmol})$ and $3.10 \mathrm{~g}$ of methacrylic acid (36 mmol) resulted in the same cluster, but with a different crystal structure due to the incorporation of $\mathrm{CH}_{2} \mathrm{Cl}_{2}$ which originates from the synthesis of $\mathrm{Cu}(\mathrm{OMc})_{2}$.

\section{$\mathrm{Cu}_{4} \mathrm{Ti}_{5} \mathrm{O}_{6}(\text { OProp })_{16}\left(2, \mathrm{C}_{48} \mathrm{H}_{80} \mathrm{Cu}_{4} \mathrm{O}_{38} \mathrm{Ti}_{5}\right)$}

Dry $\mathrm{Cu}(\mathrm{OAc})_{2}(0.182 \mathrm{~g}, 1 \mathrm{mmol})$ and $0.284 \mathrm{~g}$ of $\mathrm{Ti}(\mathrm{O} i \mathrm{Pr})_{4}$ $(1 \mathrm{mmol})$ were reacted with $1.44 \mathrm{~g}$ of propionic acid ( $24 \mathrm{mmol}$ ). The solution was clear and blue after 2 days of stirring. The solution was cooled to $-18{ }^{\circ} \mathrm{C}$ and green crystals of 2 were isolated after 2 week. Yield $0.29 \mathrm{~g}$ $(25 \%$ rel. $\mathrm{Cu})$.

Table 1 Crystal data, data collection parameters, and refinement details

\begin{tabular}{|c|c|c|c|}
\hline & 1 & 1S & 2 \\
\hline Empirical formula & $\mathrm{C}_{64} \mathrm{H}_{80} \mathrm{Cu}_{4} \mathrm{O}_{38} \mathrm{Ti}_{5}$ & $\mathrm{C}_{66} \mathrm{H}_{84} \mathrm{Cl}_{4} \mathrm{Cu}_{4} \mathrm{O}_{38} \mathrm{Ti}_{5}$ & $\mathrm{C}_{48} \mathrm{H}_{80} \mathrm{Cu}_{4} \mathrm{O}_{38} \mathrm{Ti}_{5}$ \\
\hline$M_{\mathrm{r}}$ & 1950.94 & 2120.79 & 1758.78 \\
\hline Crystal system & Triclinic & Triclinic & Monoclinic \\
\hline Space group & $P \overline{1}$ & $P \overline{1}$ & $P 2_{1} / n$ \\
\hline$a / \AA$ & $12.6918(3)$ & $13.8581(9)$ & $15.7865(9)$ \\
\hline$b / \AA$ & $12.7251(3)$ & $17.568(1)$ & $13.6433(9)$ \\
\hline$c / \AA$ & $13.5794(4)$ & $18.426(1)$ & $16.532(1)$ \\
\hline$\alpha /^{\circ}$ & $91.584(1)$ & $92.384(2)$ & 90 \\
\hline$\beta /^{\circ}$ & $69.965(1)$ & $101.229(2)$ & $108.080(4)$ \\
\hline$\gamma /{ }^{\circ}$ & $84.063(1)$ & $91.658(2)$ & 90 \\
\hline$V / \AA^{3}$ & 2034.87(9) & $4395.4(5)$ & $3384.9(4)$ \\
\hline$Z$ & 1 & 2 & 2 \\
\hline$D_{x} / \mathrm{g} \mathrm{cm}^{-3}$ & 1.592 & 1.602 & 1.726 \\
\hline$\mu / \mathrm{mm}^{-1}$ & 1.575 & 1.583 & 1.882 \\
\hline Crystal size/mm & $0.38 \times 0.33 \times 0.30$ & $0.50 \times 0.32 \times 0.14$ & $0.29 \times 0.25 \times 0.22$ \\
\hline$T_{\min }, T_{\max }$ & $0.5860,0.6495$ & $0.5050,0.8088$ & $0.6113,0.6822$ \\
\hline No. measd, indep, obs. refl. $(I>2 \sigma(I))$ & $46,053,9380,8193$ & $307,797,36,951,28,747$ & $134,762,12,959,9150$ \\
\hline$\theta_{\max } /^{\circ}$ & 27.56 & 34.42 & 33.25 \\
\hline$R\left[F^{2}>2 \sigma(F)\right], \omega R\left(F^{2}\right), S$ & $0.0260,0.0705,1.050$ & $0.0342,0.0864,1.088$ & $0.0486,0.0943,1.114$ \\
\hline No. of parameters & 510 & 1100 & 466 \\
\hline Weighting scheme* & $x=0.0328, y=1.7735$ & $x=0.0275, y=4.6424$ & $x=0.0298, y=3.7190$ \\
\hline$\delta \rho_{\max }, \delta \rho_{\min } / \mathrm{e} \AA^{-3}$ & $0.463,-0.340$ & $1.051,-0.992$ & $0.932,-1.034$ \\
\hline
\end{tabular}

* $\omega=1 /\left[\sigma^{2}\left(F_{0}^{2}\right)+(x P)^{2}+y P\right]$, where $P=\left(F_{0}^{2}+2 F_{c}^{2}\right) / 3$ 


\section{X-ray crystallography}

Crystallographic data were collected on a Bruker AXS SMART APEX II four-circle diffractometer with $\kappa$-geometry at $100 \mathrm{~K}$ using $\operatorname{MoK}_{\alpha}(\lambda=0.71073 \AA)$ radiation. The data were corrected for polarization and Lorentz effects, and an empirical absorption correction (SADABS) was employed. The cell dimensions were refined with all unique reflections. SAINT PLUS software (Bruker Analytical X-ray Instruments, 2007) was used to integrate the frames. Symmetry was checked with the program PLATON.

The structures were solved by charge flipping (JANA2006). Refinement was performed by the full-matrix least-squares method based on $F^{2}$ (SHELXL97 [9]) with anisotropic thermal parameters for all non-hydrogen atoms. Hydrogen atoms were inserted in calculated positions and refined riding with the corresponding atom. Crystal data, data collection parameters, and refinement details are listed in Table 1. Some propionate ligands of $\mathbf{2}$ show positional disorder.

CCDC 1051410 (1), 1051411 (1S), and 1051412 (2) contain supplementary crystallographic data. The data can be obtained free of charge from The Cambridge Crystallographic Data Centre via http://www.ccdc.cam.ac.uk/ data_request/cif.
Acknowledgments This work was supported by the Fonds zur Förderung der wissenschaftlichen Forschung (FWF), Austria (project P22915). The authors thank the X-ray center of Vienna University of Technology for its support.

Open Access This article is distributed under the terms of the Creative Commons Attribution 4.0 International License (http:// creativecommons.org/licenses/by/4.0/), which permits unrestricted use, distribution, and reproduction in any medium, provided you give appropriate credit to the original author(s) and the source, provide a link to the Creative Commons license, and indicate if changes were made.

\section{References}

1. Artner C, Czakler M, Schubert U (2014) Chem Eur J 20:493-498

2. Artner C, Kronister S, Czakler M, Schubert U (2014) Eur J Inorg Chem 2014:5596-5602

3. Artner C, Koyun A, Czakler M, Schubert U (2014) Eur J Inorg Chem 2014:5008-5014

4. Moraru B, Kickelbick G, Schubert U (2001) Eur J Inorg Chem 2001:1295-1301

5. Gross S, Kickelbick G, Puchberger M, Schubert U (2003) Monatsh Chem 134:1053

6. Jupa M, Kickelbick G, Schubert U (2004) Eur J Inorg Chem 2004:1835-1839

7. Czakler M, Artner C, Schubert U (2015) Monatsh Chem 146:897

8. Dam HA, Kim D (2009) Ind Eng Chem Res 48:5679

9. Sheldrick GM (1997) SHELXS-97, Program for Crystal Structure Determination. University of Göttingen, Göttingen 